\title{
PERBANDINGAN KINERJA SISTEM PENDINGIN YANG DIGUNAKAN UNTUK WATER HEATER DENGAN MENGGUNAKAN ALAT PENUKAR KALOR TIPE SERPENTINE DAN CIRCULAR
}

\author{
I Wayan Sugita, Darwin Rio Budi Syaka, Edi Dwi Saputro \\ Universitas Negeri Jakarta, Fakultas Teknik, Prodi Teknik Mesin \\ Jl. Rawamangun Muka, Jakarta Timur \\ E-mail: wayan-sugita@unj.ac.id
}

\begin{abstract}
ABSTRAK
Tujuan penelitian ini adalah untuk memanfaatkan kembali panas buang dari kondensor AC yang dibuang begitu saja ke lingkungan. Dengan mengurangi panas buang yang dikeluarkan oleh kondensor AC dapat mengurangi konsumsi listrik yang berdampak pada penghematan energi dan pengurangan efek dari pemanasan global.
\end{abstract}

Penelitian ini dilakukan selama tiga bulan dimulai pada bulan Oktober sampai dengan Desember 2015. Pada penelitian ini dilakukan pengambilan data berupa suhu air input, suhu air output, suhu udara, suhu output kompresor, suhu output kondensor, suhu output evaporator, dan suhu permukaan pipa tembaga pada heat exchanger. Sedangkan dalam pengambilan data penunjangnya dilakukan pengambilan data pada tekanan refrigerant, dan arus sistem. Pengambilan data suhu penelitian dilakukan pada 3 tekanan refrigerant yang berbeda, tekanan refrigeran 80,75 , dan 70 psi.

Hasil penelitian menunjukkkan bahwa alat penukar kalor tipe circular memberikan hasil lebih baik dibandingkan tipe serpentine. Efisiensi penukar kalor tipe circular yaitu sebesar 69,34\% pada tekanan refrigeran 70 psi dan untuk tipe serpentine yaitu sebesar 62,8\% pada tekanan yang sama.

Kata Kunci : Air Conditioner Split, Circular, Heat Exchanger, Serpentine, Water Heater

\section{Pendahuluan}

Energi sudah menjadi kebutuhan utama dalam kehidupan modern seperti sekarang ini. Krisis energi tengah menjadi isu hangat yang terjadi di berbagai belahan dunia. Krisis tersebut diakibatkan oleh penggunaan bahan bakar fosil yang berlebihan, dimana bahan bakar fosil tersebut adalah sumber daya yang tidak dapat diperbaharui. Akibatnya energi yang bersumber dari bahan bakar fosil itu sendiri semakin menipis yang berdampak langsung kesegala aspek kehidupan, seperti melonjaknya harga bahan bakar minyak maupun naiknya tarif dasar listrik.

Di tengah krisis energi seperti ini, pemanfaatan energi secara optimum harus dilakukan dengan sebaik-baiknya. Salah satunya adalah dengan memanfaatkan kembali energi yang dibuang atau biasa disebut dengan konversi energi. Konversi energi adalah sebuah upaya sistematis, terencana dan terpadu guna melestarikan sumber daya energi dan serta meningkatkan efisiensi pemanfaatannya. Manfaat yang diperoleh dengan diterapkannya efisiensi energi diantaranya adalah penghematan energi fosil yang selama ini digunakan untuk menghasilkan listrik, pengurangan emisi gas rumah kaca yang merusak lingkungan hidup hingga penghematan biaya listrik.

Salah satu contoh energi yang dibuang begitu saja ke lingkungan yang terjadi di sekitar kita dapat kita temukan pada pemakaian AC (Air Conditioner). Aplikasi pemanfaatan kembali energi yang dibuang pada sistem AC adalah dengan Air Conditioner Water Heater (ACWH) yaitu dengan memanfaatkan panas buang dari kompresor AC untuk memanaskan air sehingga dapat digunakan kembali untuk mandi dan keperluan lainnya yang membutuhkan air hangat. Sistem ini bekerja dengan menggunakan alat penukar kalor yang dipasang pada sistem AC sehingga tidak 
membutuhkan energi tambahan, tetapi memanfaatkan energi yang ada dalam sistem AC tersebut. Dengan menggunakan sistem tersebut, kita memiliki beberapa keuntungan sekaligus yaitu efek pendinginan ruangan, efek pemanasan air hemat energi dan juga kita bisa melakukan penghematan baik dari energi maupun biaya yang harus kita keluarkan. Melihat begitu banyaknya keuntungan dengan penggunaan ACWH, penulis ingin meningkatkan pemakaian ACWH di msyarakat. Untuk itu perlu kita ketahui alat penukar panas mana yang paling maksimal dalam menghantarkan panas, maka dipilihlah tipe water heater yang akan digunakan yaitu tipe Serpentine dan tipe Circular. Kedua alat penukar panas tersebut akan dibandingkan agar dapat diketahui kinerja dari masing masing alat penukar panas tersebut.

\section{Metode Penelitian}

2.1 Tujuan Penelitian

1. Mengetahui pengaruh penambahan sistem heat exchanger pada kompresor AC split $1 \mathrm{PK}$ ?

2. Mengetahui Heat exchanger manakah yang menghantarkan panas yang lebih baik?

2.2 Tempat dan Waktu Penelitian

Penelitian ini dilakukan di bengkel AC Harapan Jaya Teknik Sunter Jaya Jakarta Utara selama tiga bulan, dimulai pada bulan Oktober sampai Desember 2015. Pengujian ACWH di ruangan yang berukuran $10 \mathrm{~m}^{2}$ menggunakan AC Split Panasonic 1 PK.

2.3 Prosedur Penelitian

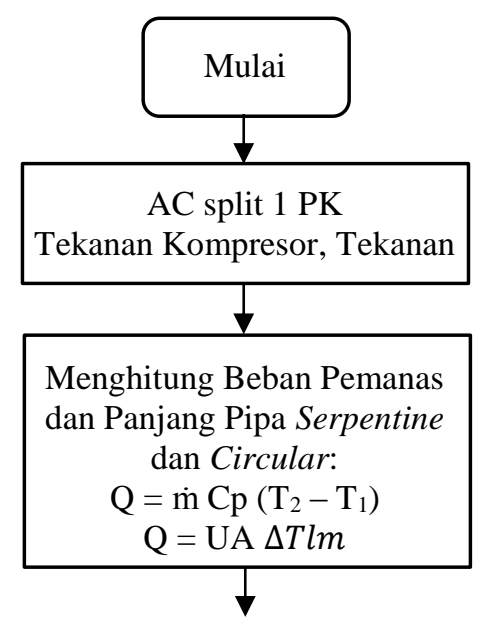

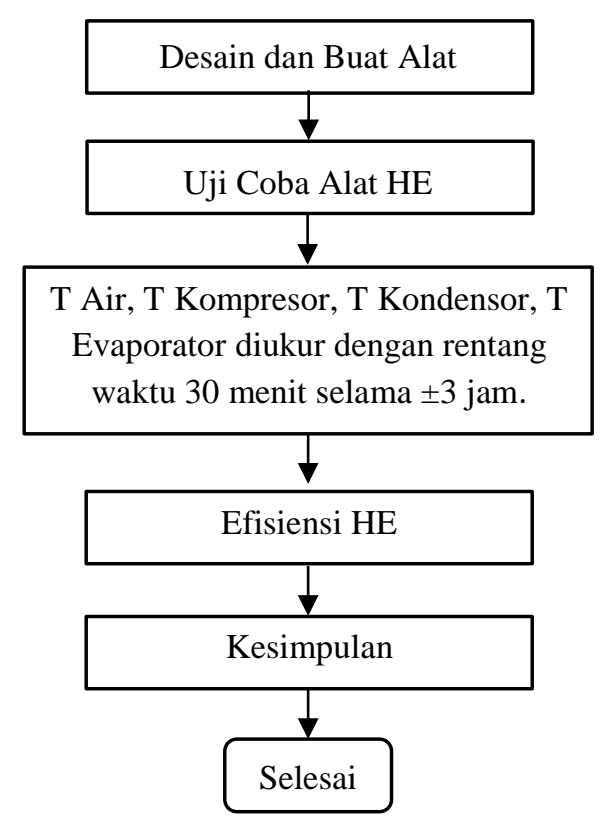

Gambar 2.1 Diagram Prosedur Penelitian

\section{Hasil dan Pembahasan}

\subsection{Pengujian Air Conditioner Water Heater}

Pada pengujian ini diawali dengan mengisi tangki water storage dengan air sejumlah 50 liter, lalu mengisi refrigerant dengan menggunakan musicool 22 yang bertekanan 80, 75 dan 70 psi. Setelah itu dilakukan pengukuran suhu awal dari udara sekitar dan suhu air yang dimasukan ke dalam tangki. Setelah semuanya selesai dilanjutkan dengan menyalakan AC (air conditioner).

Pengambilan data dilakukan dengan cara mengukur suhu keluar dari kompresor, kondensor, evaporator dan suhu keluar dari heat exchanger serta mengukur suhu air yang ada didalam water heater. Pengukuran suhu $\left({ }^{\circ} \mathrm{C}\right)$ menggunakan thermometer digital. Thermometer ini diletakkan pada permukaan pipa tembaga kompresor, kondensor, evaporator, dan pipa keluar heat exchanger. Untuk suhu air, termometer ini diletakan pada bagian dalam water storage. Berikut ini adalah hasil pengujiannya : 


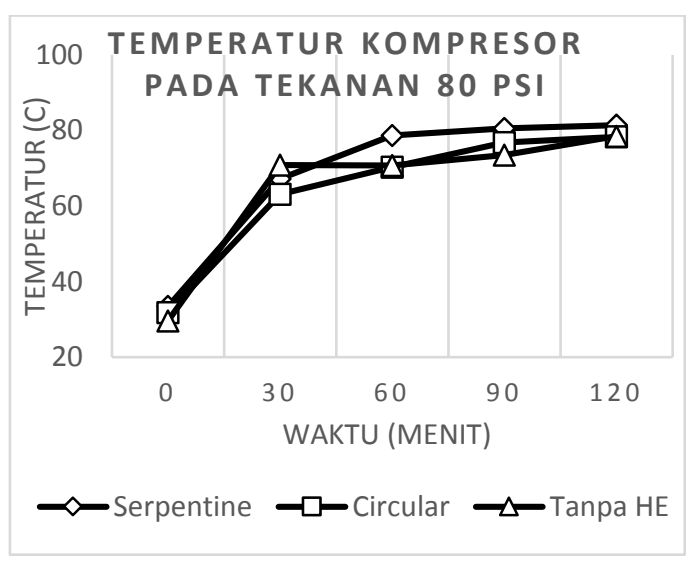

Grafik 1. Temperatur Kompresor Terhadap Waktu

Temperatur hasil pengukuran pada kompresor antara penukar kalor serpentine, circular dan tanpa penukar kalor menunjukkan tidak terjadi perbedaan yang signifikan.

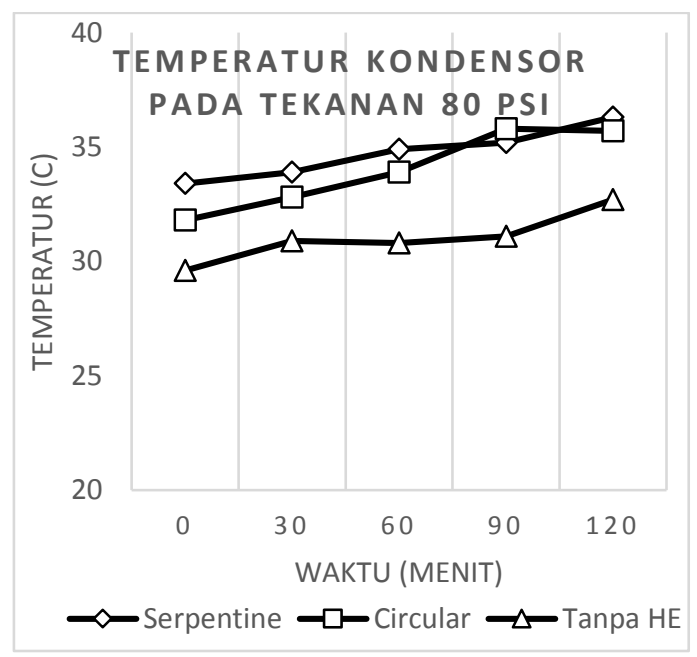

Grafik 2. Temperatur Kondensor terhadap Waktu

Temperatur hasil pengukuran pada kondensor antara pemasangan penukar kalor serpentine, circular dan tanpa penukar kalor memperlihatkan adanya perbedaan.

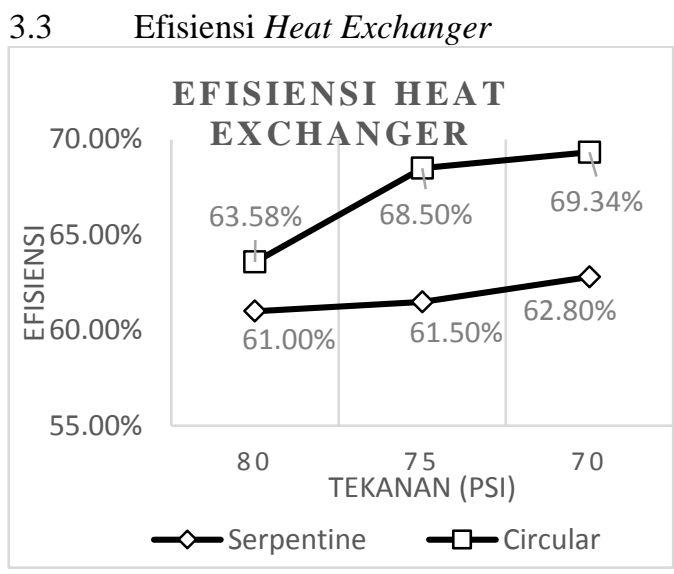

Grafik 3. Efisiensi Heat Exchanger

Grafik 3 menunjukkan terdapat perbedaan efisiensi antara penukar kalor tipe serpentine dengan penukar kalor tipe circular. Efisiensi tertinggi oleh penukar kalor tipe serpentinecircular pada tekanan 70Psi sebesar 69,34\%. Sedangkan efisiensi penukar kalor tipe serpentine pada kondisi yang sama sebesar $62,80 \%$.

\section{Kesimpulan}

Berdasarkan analisa yang didapatkan selama pengujian, dapat diambil beberapa kesimpulan:

1) Penambahan heat exchanger pada AC tidak berpengaruh besar terhadap temperatur kompresor yang dihasilkan, ini terbukti dengan temperatur hasil pengukuran antara serpentine, circular maupun tanpa alat penukar kalor perbedaan pengukuran suhunya tidak terlalu signifikan.

2) Efisiensi heat exchanger tipe serpentine dan circular yang baik terdapat pada tekanan refrigeran 70 psi yaitu sebesar $62,8 \%$ untuk serpentine dan $69,34 \%$ untuk circular. 


\section{Daftar Pustaka}

1. Holman, J.P., E, Jasjfi. 1995. Perpindahan Kalor. Jakarta: Erlangga.

2. Incropera, Frank P., et al. 2002. Fundamentals of Heat and Mass Transfer. Singapore: John Wiley \& Sons (Asia) Pte. Ltd.

3. Irawan, Setia R. 1998. Split Air Conditioner. Jakarta: BLKI.

4. K, Handoko. 1979. Teknik Room Air Conditioner, Jakarta: PT. Ichtiar Baru.

5. Kurniawan, Iwan. 2000. Merawat \& Memperbaiki AC. Jakarta: Puspa Swara.

6. Nurbambang, Soufyan M., Marimura, Takeo. 1986. Perancangaan \& Pemeliharaan Sistem Plambing. Jakarta: Pradnya Paramita.

7. Nurhalim, Ichwan. 2011. Rancang Bangun \& Pengujian Unjuk Kerja Alat Penukar Kalor Tipe Serpentine Pada Split Air Conditioning Water Heater. Skripsi Program Sarjana Fakultas Teknik UI: Depok.

8. Untoro, Joko., dkk. 2010. Buku Pintar Pelajaran: Ringkasan Materi dan Kumpulan Rumus Lengkap. Jakarta: PT. Wahyu Media
9. Fitrianingtias, Shely Diah. (2010) "Perpindahan Panas Pola Aliran, Temperatur Dan Klasifikasi Heat Exchanger" (online). Jurusan Teknik Kimia. Samarinda: Politeknik Negeri Samarinda. Tersedia di: http://id. scribd.com/doc/94414016/HeatExchanger. (Diunduh tanggal 7 Oktober 2015)

10. Hamid, Ahmad Abu (2007) "Kalor dan Termodinamka". Tersedia di: http://staff.uny.ac.id/sites/default/fil es/Diktat\%20Termodinamika.pdf. (Diunduh tanggal 12 Desember 2015)

11. Hariyanto, Dedi (2010) "Heat Exchanger (Alat Penukar Panas)". Tersedia di: https://www.scribd.com/doc/12715 5281/16/Jenis-jenis-Heat-

Exchanger. (Diunduh tanggal 13 Desember 2015)

12. http://teknikelektronika.com/penger tian-daya-listrik-rumus-caramenghitung/, diakses pada 16 September 2015.

13. http://www.cara.aimyaya.com/2015 101/rumus-menghitung-volumetabung-silinder.html, diakses pada 16 September 2015. 